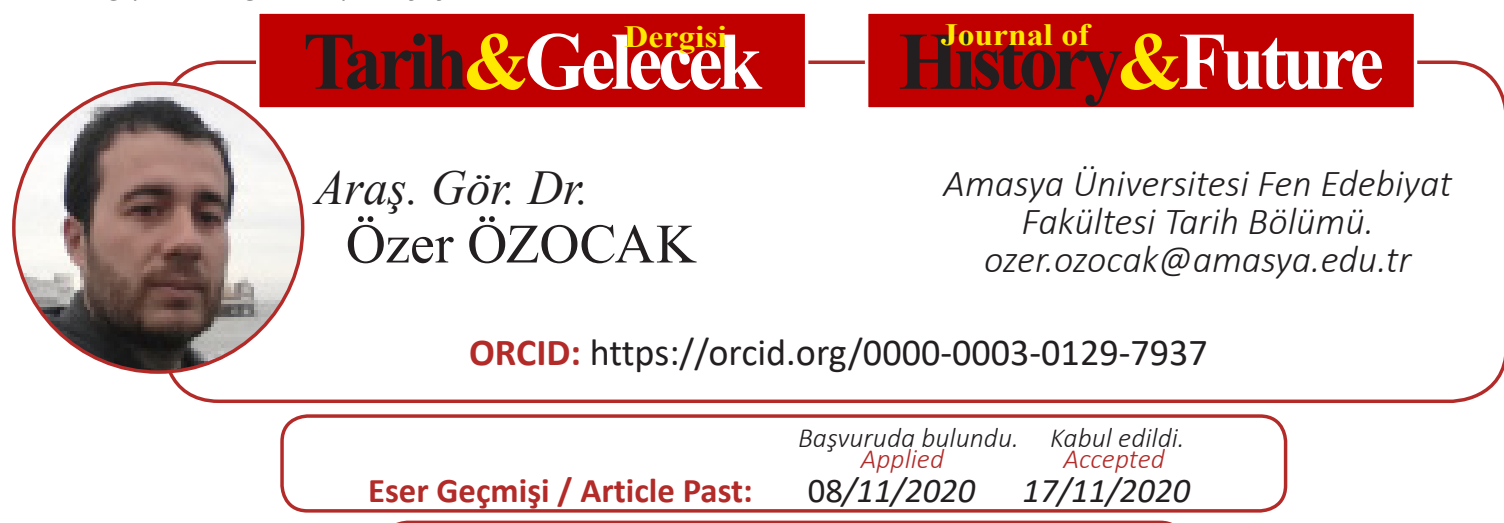

Araştırma Makalesi

DOI: http://dx.doi.org/10.21551/jhf.823041

Research Paper

Orjinal Makale / Orginal Paper

\title{
13 Teşrin-i Sani 1329 Tarihli Peyam Gazetesi'nde "Vereme Karş1 Nasihatler" Adıyla Yer Verilen Nasihatnâmeden Hareketle Osmanlı Devleti’nin Son Döneminde Veremle Mücadele Üzerine Bir İnceleme
}

(An Investigation on the Struggle Against Tuberculosis in the Last Period of the Ottoman Empire, Based on the Advice Given as "Advice Against Tuberculosis" in Peyam Newspaper Dated 13 November 1329)

Önce öksürüverdim

Öksürüverdim hafiften

Derken ağzımdan kan geldi

Bir ikindiüstü durup dururken ${ }^{1}$

ÖZ

Verem ya da diğer bir değişle Tüberküloz, salgınlar tarihinin en ciddi hastalıklarındandır. $\mathrm{Bu}$ hastalık, tarihi süreç içerisinde çok sayıda insanın hayatını acılar içinde kaybetmesine yol açtı. İnsanların temel besin kaynaklarına daha rahat ulaşır olmaları ve barınma koşullarındaki iyileşmeler gibi olumlu gelişmelerle birlikte ölümcül etkisi yok denecek derecede azaldı. Temizlik malzemelerinin kişiselleştirilmesi ve bünyeye zarar verecek şeylerden uzak durulması da hastalıktan sakınmak adına en yararlı tutumlar olarak görülmektedir. Veremin ölümcül hastalıklar listesinde arka sıralara gitmesinde, tıp alanındaki teknolojik gelişmelerin de çok büyük rolü vardır. Hastalığın erken tanısına imkân sunan yeni aletler, tedavi sürecinde de hızlaştırıcı etkiyi sahip oldular. Modern tıbbın tavsiyeleri bağlamında bugünden bakıldığında, bireylerin bilinçlendirilmesi faaliyetleri de hastalığın etkisinin azaltılmasında başta gelen unsurlardandır. Bu kapsamda, Osmanlı Devleti'nin son yıllarında ve Cumhuriyet döneminde çok sayıda yayın yapıldı. Bunlar arasında Peyam Gazetesi'nde "Vereme Karşı Nasihatler" başlığıyla yer alan nasihatnâme içeriği ve tavsiyeleri ile oldukça dikkat çekicidir.

\footnotetext{
1 Muzaffer Tayyip Uslu, Şimdilik, Yapı Kredi Yayınları, İstanbul 2017, s.46.
}

ATIF: ÖZOCAK Özer, "13 Teşrin-i Sani 1329 Tarihli Peyam Gazetesi'nde "Vereme Karşı Nasihatler" Adıyla Yer Verilen Nasihatnâmeden Hareketle Osmanlı Devleti'nin Son Döneminde Veremle Mücadele Üzerine Bir İnceleme ", Tarih ve Gelecek Dergisi, 6/4 (Aralık 2020), s. (1219-1234) 
Anahtar Kelimeler: Osmanlı Devleti, Cumhuriyet, Verem, Salgın, Virüs.

\begin{abstract}
:
Tuberculosis is the most serious diseases in the history of epidemics. This disease, caused many people to lose their lives in pain during the historical process. With positive developments such as people's better access to basic food sources and improvements in housing conditions, the lethal effect has diminished to almost no extent. Personalizing cleaning materials and avoiding things that will harm the body are also seen as the most beneficial attitudes in order to avoid disease. Technological developments in the field of medicine have a great role in the fact that tuberculosis ranks behind the list of deadly diseases. New devices that allow early diagnosis of the disease also have an accelerating effect in the treatment process. When viewed from today in the context of the recommendations of modern medicine, awareness-raising activities are also one of the leading factors in reducing the impact of the disease. In this context, many publications were made in the last years of the Ottoman Empire and in the Republic period. Among these, the advisory content and recommendations of the "Advice Against Tuberculosis" in Peyam Newspaper are quite remarkable.
\end{abstract}

Keywords: Ottoman State, Republic, Tuberculosis, Epidemic, Virus.

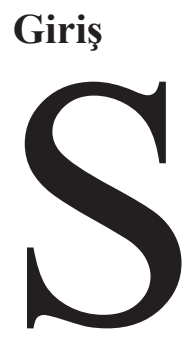
algın kelimesi, sözlüklerde birden fazla şekilde tanımlanmaktadır. Örneğin, Osmanlıaskerlerininçöldebinbirtürlüzorluklaryaşamalarına yol açançekirgelerin yer değiştirme hareketleri de istila ya da salgın kelimesi ile karşılanmaktadır. Esasen bu kullanım biçiminin kelimenin kullanıldı̆̆ı diğer alanlarla ortak yanı yayılma, genişleme ve etki alanını büyütme anlamlarını karşılamasıdır. Modern insanın beynindeyse kavram, daha çok hızla yayılarak sayısız canlının hayatını kaybetmesi ya da ciddi hasarlar almasına sebebiyet veren hastalıklara karşı gelmektedir. Covid 19' da bilgisayarlar ve cep telefonları gibi modern iletişim araçları ile mesajlaşma, sesli ve görüntülü arama yanı sıra uçak ve hızlı tren gibi ulaşım vasıtaları ile çok uzun mesafelere daha hızlı ve rahat bir biçimde ulaşma olanağı edinen 21. Yüzyıl insanı için tam manasıyla bir salgındır. Ortaya çıkışı ile ilgili farklı iddiaların olduğu gerçeği bir yana salgın kavramının karakteristik özelliklerini taşıyarak kısa bir sürede günümüz insanının hayatını kolayca alt üst etme güç ve kabiliyetini gösterdi.

Bu virüs, dünyanın farklı kıtalarında ve standartlarının birbiriyle uyuşmadığı çeşitli ülkelerde, benzer zaman dilimlerinde ve birbirlerini takip eder nitelikte Sıkı Yönetim(OHAL) ilanlarını zorunlu kıldı. Bu noktada salgın hastalıkların dünya tarihinin farklı dönemlerinde çok büyük etkilerinin olduğunu da belirtmemiz gerekir. Bu hastalıkların başlıcaları cüzzam, veba, kolera, çiçek, tifüs ve influenzadır. Tevrat'ta bunlardan cüzzama yakalanan hastaların sokaklarda dolaşırken “murdar... murdar..." diye mırıldanarak ya da dilsiz olmaları durumunda boylarına bir çan takarak yürümek zorunda olduklarına yer verilmektedir. ${ }^{2} 1492$ tarihli bir Osmanlı kroniğinde, Mısır'da vebadan

2 Hikmet Özdemir, Salgın Hastallklardan Ölümler 1914-1918, Türk Tarih Kurumu, Ankara 2005, s. 17. 
600.000 civarında insanın yaşamlarını yitirdiklerinden bahsedilmektedir. ${ }^{3}$ Daniel Defo etkisini gösterdiği yerlerde benzer trajedilerin yaşanmasına neden olan vebanın İngiltere'de yol açtığ yıkımlara eserinde yer vermektedir. Ona göre, hastalık ilerledikçe insanlarda öfke patlamaları ve büyük hissi yıkımlara sebep olmaktadır. Hastalar çektikleri acılardan dolayı kendilerine zarar vermeye başlamaktadır. Vebalılardan bazıları kendilerine dar gelen mekânların duvarlarını elleri ile parçalamakta, izdıraplarına son vermek için pencerelerden atlamakta ya da ellerine geçirdikleri bir silah yoluyla canlarına kıymaktadır. Katlanılamaz acılar karşısında çaresiz kalan anneler cinnete kapılarak çocuklarını öldürmektedir. Hasta olmayanlar dahi vebanın yol açtığı yıkımlar karşısında panikle bunalıma girmekte, akıllarını kaybetmekte ya da hayatlarını yitirmektedir. ${ }^{4}$

Salgın hastalıklardan koleraysa, I. Dünya Savaşı yıllarında Arabistan çöllerine değin uzandı. ${ }^{5}$ 1 Temmuz 1839'da Sultan II. Mahmud'un ve 25 Haziran 1861'de selefi Sultan I. Abdülmecid'in hayatlarını kaybetmelerine sebep olan ve kısa zaman dilimlerinde çok geniş coğrafyalara sirayet eden bulaşıcı hastalıklardan biri de veremdir. ${ }^{6}$ Cumhuriyetin ilk yıllarında toplam nüfus 13 milyon iken bu sayının 1 milyonu belirtilen hastalığa yakalandı. ${ }^{7} \mathrm{Bu}$ rakam bile hastalığın yurdumuzda ulaştığı boyutları ve dünyaya paralel olarak ülkemizde vereme ilişkin mücadeleyi ele almayı zorunlu kılmaktadır. Bu bağlamda çalışmamızda, sıradan halkın bilinçlendirilmeye çalışıldığı veremin tarifinin, çeşitlerinin ve yayılma yollarının, veremden nasıl sakınılabileceğinin ve hastalığa yakalanan kişilerin nelere dikkat etmeleri gerektiğinin üzerinde duruldu. Bu kapsamda Peyam Gazetesi'ndeki nasihatnamenin yanı sıra Osmanlı arşivinde yer alan belgelere ve tetkik eserlere başvuruldu.

\section{Veremin Ele Alınışı ve Tanımlanması}

Peyam Gazetesi’nin 13 Teşrin-i Sani 1329 tarihli sayısında verem hadisesinin ele alınmasında, Osmanlı padişahlarının yaşamlarını yitirmelerine neden olacak derecede etkili bir salgın olmasının rolü büyüktü. Rüstem Paşa imzası ile 8 Haziran 1892'de İstanbul'a Said Paşa'ya gönderilen telgrafnâme de salgının gücünü başka bir Osmanlı Padişahı'na dair bir haber üzerinden ortaya koymaktadır. Bu telgrafnâmeye göre İngiliz Daily Mail Gazetesi, II. Abdülhamid'in de vereme yakalandığını okuyucularına aktarmaktadır. ${ }^{8} \mathrm{Bu}$ ilgi çekici iddiaya da neden olan hastalık, çok kolay yayılmasından ve ciddi etkilerinin olmasından ötürü topyekun bir mücadeleyi de gerektirmektedir. Nitekim Cumhuriyet döneminde, "İstanbul Verem Savaş Derneği" ve "Ankara Verem Savaş Derneği" gibi yapiların oluşturulması da toplumun bütün fertleri ile hastalıkla mücadelede rol alması gerekliliğinin bir sonucudur. Bu geniş kapsamlı savaşın unsurlarından biri de ele alacağımız nasihatnâmedir. Nasihatnâmeye "Irk ve neslimizi tahrip eden emrazdan bilhassa veremin her sene memleketimizde bir Balkan Harbi kadar kurban alıp götürdüğ̈̈ malumdur"

3 Mesut Ayar-Tarık Özçelik, “19. Asır Ortalarında Kadar Osmanlı”da Veba Salgın Tarihçesi”, Osmanlı'da Salgin Hastallklarla Mücadele, Editörler: İbrahim Başoğlu vd, Çamlıca, İstanbul 2015, s.51-52.

4 Daniel Defo, Veba Yılı Günlüğ̈̈, Çeviren: İris Kantemir, Türkiye iş Bankası Kültür Yayınları, İstanbul 2020, s.79

5 H. STJ. Philby, Arabian Jubilee, Robert Hale Limited, London 1952, s.18.

6 Özdemir, Salgın Hastalıklardan Ölümler, s.77.

7 Fatih Tuğluoğlu, "Cumhuriyet'in Illk Döneminde Verem Mücadelesi ve Propaganda Faaliyetleri", Yakın Dönem Türkiye Araştırmaları, S. 13-14, 2008, s.1-26.

8 COA, HR.SYS, Dosya No: 3, Gömlek No: 720, Tarih: M.08.06.1892. 
cümlesi ile hastalığın önemine binaen ciddiye alınması vurgusu ile başlanmaktadır. Gazetede, verem konusunun ele alınmasına, hastalığa karşı bireylerin bilinçlendirilmesi ve farkındalık oluşturulmasını sağlamak üzere tertip edilen bir dizi etkinliğin vesile olduğu belirtilmektedir. $\mathrm{Bu}$ kapsamda, Gülhane Seririyat Hastanesi'nde sergi açıldı. Sergiye, kadınlara ve erkeklere yönelik konferanslar eşlik etti. Bu etkinlikler kapsamında katılımcılara, herhangi bir ücret talep etmeksizin nasihatnâmenin birer örneği dağıtıldı.

Belirtilen yayın çok geçmeden Peyam Gazetesi'nin sayfalarına "Karilerimizin bunu dikkat ve emniyetle telâkki edecekleri ümidindeyiz” girişi ile yansıtıldı. Bu giriş ile aynı zamanda gazetenin okuyucularından nasihatnâmeye ilişkin beklentilerinin ne yönde olduğuna ve nasihatnâmenin önemine yer verildi. Takiben "Verem nedir?" sorusu sorularak hastalığın tanımlanması yoluna gidildi. İlkin salgın hastalıkların fertler üzerinde büyük tesirler bıraktığı ve vücudun farklı bölgelerinde hastalığa yol açmasına rağmen ağırlıklı olarak ciğerlerde görüldüğü yazılmaktadır. Toplumun bütün unsurlarının hastalığa yakalanma tehdidi ile karşı karşıya olduğu belirtilmektedir. $\mathrm{Bu}$ tarihlerde İstanbul sınırları içerisine 28.000 kişinin rahatsızlığa yakalandığı ve her yıl 2.700 dolaylarında vatandaşın hastalığa yenik düştüğü ifade edilmektedir. "Vatandaş!” nidasıyla taşra ahalisinin ne derece yoğun bir biçimde verem illetine tutulduğu ve "bulunduğun yekûnun önünde titre! Bak! Bu milletin yuvarlanıp gittiği daha ne derin uçurumlar var" denilerek de okuyucunun geçirilen sıkıntının boyutlarını göz önüne alması lüzumu dile getirilmektedir. ${ }^{9}$

Nasihatnâmenin okurlarını uyardığı hastalığa, 300 milyon yıldır topraklarda, sularda, çayırlarda, çimenlerde ve petrol atıklarında çok sayıda bulunan Mycobacterium Tuberculosis (MT) yol açmaktadır. ${ }^{10}$ Tüberküloz bakterilerinin ne zamandan beri var olduklarına dair bu eski tarihlendirmenin ötesine de geçilmektedir. Bakterilerin canlılıkları, insanların sığırları evcilleştirip, sığındıkları dar mekânlarda dâhil olmak üzere, birlikte yaşamaya başladıkları 7000 yıl öncesine kadar götürülmektedir. Diğer taraftan meşhur Hipokrat, veremin Eski Yunan'ın en ölümcül ve yaygın hastalığı olduğu kanısı ile çok eski zamanlarda da yıkıcı bir güce sahip olduğunu ortaya koymaktadır. ${ }^{11}$ Diğer taraftan "Verem hastalı̆̆ının sebepleri ve ortaya çıkması ile alınması gereken tedbirler" adlı Osmanlı arşivinde yer alan belgede veremin ne olduğuna ilişkin bazı bilgilere yer verilmektedir. Bu belgeye göre mikrop yani basil, vereme yol açmaktadır. $\mathrm{Bu}$ mikroplar, insan vücudunda yer edinirler ve hastaliklara neden olurlar. Verem basilleri havada, toprakta, suda, yiyeceklerde ve giyeceklerde canlılıklarını korurlar. Kış aylarının en soğuk ve yaz mevsiminde en sıcak günlerinde bile temizliğine dikkat edilmeyen yerlerde hayatiyetlerini korumaya başarırlar. Kışlalar, okullar ve hastaneler gibi ortak kullanım alanlarında sayıları daha fazladır ve insandan insana daha kolay geçmektedir. ${ }^{12}$

Peyam da ise, verem hastalığına yol açan mikrobun gözle görünmeyecek derecede küçük

9 “Vereme Karşı Nasihatler”, Peyam, 13 Teşrin-i Sani 1329 (26 Kasım 1913), s.4.

10 İzzettin Barış, "Çağlar Boyu Tüberküloz”, 21. Yüzyılda Tüberküloz Sempozyumu ve II. Tüberküloz Laboratuarı Tanı Yöntemleri Kursu, Samsun, s.1-7.

11 Andrew Nikiforuk, Mahşerin Dördüncü Atlısı, Çeviren: Selahattin Erkanlı İletişim, İstanbul 2008, S. 170 .

12 Diğer taraftan makalemizde sık sık yer vereceğimiz bu arşiv belgesinde ağırlıklı olarak akciğerlere yerleşmekle beraber kemiklerde, boyundaki bezlerde, dimağ zarında, karın içinde ve hatta bağırsaklarda bile ortaya çıkabileceğinin üzerinde durulmaktadır. COA, Y.PRK.ASK, Dosya No:139, Gömlek No: 92 , Tarih: H.12.01.1316 ( 02.06.1898). 
olduğu ve sadece mikroskop vasıtasıyla görülebileceğini yazılmaktadır. Nasihatnâmeye göre mikrop, insanların ve hayvanların bünyelerinde yer edindikten sonra belirli bir olgunlaşma süreci geçirmektedir. Süt, tükürük, cerahatler, pislikler ve idrar gibi yollarla etrafa yayılmaktadır ve insanların tamamına bulaşma riski vardır. Virüsler, etkisi altına aldığı bazı kimselerde yaygın belirtilerini göstermeksizin yaşamayı sürdürebilirler. Mikroba en ağır darbeyi rutubetli hava ile yüksek sıcaklık indirmektedir. Mikroplar, dik gelen güneş ışınlarına dayanamamakta ve sıcaklığın tesiri ile 20 dakikada ölmektedir. Mikroplara savaş açan bazı ilaçlar ön plana çıkmaktadır; ancak bu ilaçların kullanım şekilleri ve dozajlarının öğrenilmesi gerekmektedir. Bu ilaçların nasıl kullanılacağı bilinmeden alınması ve hastalığa karşı özensiz hareket edilmesi halinde istenilen sonuç alınamayacaktır. ${ }^{13}$

\section{Veremin Türleri ve Yayılımı}

Tedavisinin ciddi bir mücadele gerektirdiği verem, yakalananları günden güne ölüme sürüklediğinden bizde "ince hastalık, teverrüm, zaafiyet, duman" olarak adlandırılırken, Batı'da "tüketim hastallğı (consumption)", "beyaz ölüm (whitedeath)", "beyaz veba (whiteplague)" ve "ölümün kaptanı (captain of the death)" diye de anılırdı. ${ }^{14}$ Genellikle ölümle sonuçlanan salgın hastalıkta, verem mikroplarını ağız ya da burundan alan çocuklarda görülen belirtinin ilki, çene altlarında bulunan bezlerin büyümeye başlamasıdır. Bu bölgeden verem bezlerin hattı boyunca ilerleyerek beyin zarına ulaşır ve buraya yerleşir. Mikrop ihtiva eden tozların solunması ile vücuda giriş yapar. Ciğerlere doğru yayılarak buraları hasta eder ve buna ciğer veremi adı verilir. Pek sık görülmemekle birlikte gırtlak bölgesinde yaşamayı sürdürdüğüne de rastlanır. Böylece adını aldığı gırtlak bölgesinden hareketle gırtlak veremine sebep olur. Yetişkinlerde Lopus denilen ve mikrobun tozlarla derinin canlılığın yitirmesine neden olan deri veremine yol açar. Ciğerde görülmesi ile ortaya çıkan ciğer veremi çoğunlukla yavaş yavaş silinebilir. Müzmin ya da hızla gelişme kaydetmesinden dolayı Koşucu Verem olarak adlandırılan veremse çoğunlukla kısa zamanda hastayı öldürür. ${ }^{15}$

Verem hastalığı, Osmanlıca bir belgede "verem illet-i müdhişesi" olarak da adlandırılmaktadır. Aynı belgede, hastalığın çeşitli yaygın etkilerinin görülmeye başlanması üzere kolera ve veba türündeki felaketlerden biri olarak insanlar arasında süratle yayılma eğilimi gösterdiğine dikkat çekilmektedir. Belirtilerine rastlanan kimselerde zamanla yıkımlar yarattığından ve ateş ile insan ve hayvana bulaştığ 1 vurgulandıktan sonra "sirayeten intikal ve intişar eder" denilerek yayılmacı bir yapıya sahip olduğuna değinilmektedir. ${ }^{16} \mathrm{Bu}$ noktada insanlık tarihinin farklı dönemlerinde ortaya çıkan bir bulaşıcı hastalığın ilk vakalarının nerede görüldügünün ve yayılma rotasının tarihi kaynaklara da konu edildiğini de belirtelim. Örneğin, hacıların dini görevlerini icra ediş süreçlerinin daha sorunsuz gerçekleşmesini temin için karşılaşılan eksiklerin tespitini ve giderilmesini sağlamak maksadıyla rapor hazırlayan ve dönemin Osmanlı Padişahı II. Abdülhamid'e sunan M. Şakir Bey, bulaşıcı hastalıkların dünya üzerine sirayet tehdidine ilişkin olası rotalardan birine raporunda yer

13 "Vereme Karşı Nasihatler”, s.4.

14 Kadircan Keskinbora, “Savaştaki Düşmanlardan Bir Diğeri: Tüberküloz”, Lokman Hekim Dergisi, S.6, İstanbul 2016, s.174-184.

15 "Vereme Karşı Nasihatler", s.4.

16 COA, Y.PRK.ASK, Dosya No:139, Gömlek No: 92, Tarih: H.12.01.1316 ( 02.06.1898). 
vermektedir. Raporda, Batılı tabipler ve ilim adamlarının Bahr-1 Ahmer (Kızıldeniz) civarına koleranın Kızıldeniz’i Aden Körfezi'ne bağlayan Babülmendep Boğazı ya da Süveyş Kanalı'ndan ve buralardan da Avrupa kıtasına yayılacağını değerlendirdiklerinden bahsedilmektedir. ${ }^{17}$ Süleyman Şefik Söylemezoğlu, M. Şakir Bey’in yazdıklarının ötesine geçerek, bölgenin neden uzak yerlere de hastalıklar için taşıyıcı etki yaratabileceği cevabını vermektedir. Ona göre, İngilizlerin çeşitli yollarla Hicaz'a getirdikleri hacı adayları maddi durumları olmadığından biçare vaziyetteydiler ve Cidde limanına indikleri ilk andan itibaren bulaşıcı hastalıklara karşı oldukça zayıf durumdaydılar. Belirtilen topluluk çaresizlikleri ile hastalıklara kolay yakalanma ve taşıyıcı olma potansiyelleri ile bölgeyi salgın hastalıkların gelişmesi ya da taşınmasına müsait hale getirmekteydiler. Bunlar aynı zamanda faili oldukları ya da karıştıkları olaylarla Osmanlı topraklarını asayiş açısından da tehdit oluşturmaktaydılar. ${ }^{18}$

Nasihatnâmede, dünya tarihinin bir evresinde patlak veren salgının muhtemel yayılma rotası ve taşıyıcılarına değinildikten sonra insanların veremli olarak yeryüzüne gelmedikleri ve belirtilen illete yaşarken yakalandıkları bilgisine yer verildi. Yine bu nasihatnâmeye göre, verem mikropları çok sayıda yolla bulaşabilecektir. Bulaşma yollarından belli başlıları ise şu şekilde maddeler halinde siralanmaktadir:

Teneffüs ettiğimiz hava ile: Ya ciğer veremlilerin kurumuş balgam ve tükürükleri vasıtasıyla! Bunlar toz haline gelerek veya rüzgârla ağzımıza, burnumuza girer bir gün veya kunduralarımız altına yapışarak elbiselerimiz üzerine tutunarak oradan bir suretle vücudumuza sokulur veyahut verimlinin öksürürken, aksırırken, konuşurken etrafa saçtı̆̆ küçük tükürük damlacıkları ile.

Yenecek şeyler ile: Evvela kaynatmadan içilen süt ile baytar muayenesinden iyi geçmemiş veya hiç olmamış hayvan etlerinden yapılan sucuk ve pastırmaların çiğ olarak yenmesi ile.

Derinin, ă̆ız ve burun derisinin çatlaklarından geçer. Hususuyla buralara kirli ellerin dokunmasıyla: Mesela çocuklar yerde tozlanmış, kirlenmiş oyuncaklarını tutar, bu ellerini yıkamadan yüzüne sürer, ă̆ızlarına sokar, burunlarını karıştırırlar ve bu suretle verem mikropları derinin içine ăgzın, burnun ince derisine sokarlar.

Kirli ev eşyası vasıtasıyla geçer: Mesela başkalarının kullandığı su bardağı, kahve fincanı, yemek takımları çocukların düdükleriyle ve oyuncaklarıla nihayet ellerde, yüzlerde, vücudun her tarafında olan küçük sivilce ve çatlakların temiz tutulmaması ile mikrop bu yerlerden vücuda girer. ${ }^{19}$

Nasihatnâmedeki bulaşma yollarına ilişkin bu maddelerden de anlaşılacağı üzere hastalık türlü yollarla ve kolay bir biçimde insandan insana geçmektedir. Buna karşın verem hastalığının ortadan kaldırılması için farklı ülkelerde sayısız bilimsel çalışma yapıldı ve tedavi yönetimi denendi. Hastalıkla mücadele etmeye çalışan hekimler, en çok da verem aşısı denilince ilk akla gelen isimlerden olan Alman bilim adamı Koch'un hüsranla sonuçlanan yöntemini uygulamaya çalıştılar. Ayrıca hastalığın tedavisi uğrunda kan akıtma, fosforik asit, Boa yılanı idrarının yanı sıra hastaların kaburga kemiklerini kesmekten akciğerlerini söndürmeye ve sayısız röntgen çekimine değin türlü metotlara başvurdular. Bu denemelere maruz kalan kişilerin midelerini tarumar ettirip

17 Halife 2. Abdülhamit”in Hac Siyaseti M. Şakir Bey”in Hicaz Hatıralarl, Hazırlayanlar: Gülden Sarıyıldız- Ayşe Kavak, Timaş, İstanbul 2009, s.38.

18 Süleyman Şefik Söylemezoğlu, Hicaz Seyahatnamesi, Hazırlayanlar: Ahmet Çaycı-Bayram Ürekli, İz Yayınc1lık, İstanbul 2012, s.151.

19 "Vereme Karşı Nasihatler”, s.4. 
karaciğerlerini iflas ettirmeye kadar türlü fecaatlere sebep oldular. ${ }^{20}$

\section{Veremden Korunma Yolları}

18 ve 19.Yüzyıllarda romanların başlıca konularından biri olan verem, Avrupa'daki ölümlerin en önemli sebeplerindendi. Kıtadaki yoksullarla beraber sanatçılarda hastalığın kurbanları arasındaydı. Hatta John Buryan, "ölümün bütün adamlarının reisi" olarak adlandırmak suretiyle hastalığın yol açtığı kırıma işaret etti. Mezarlık şairlerinin arasında ismi geçen John Keats 1819'da "gençlik solar, hayalet gibi zayıflar ve ölür" diye yazdıktan iki yıl sonra, henüz 26 yaşındayken, veremden hayatını kaybetti. Veremli hanelerde hastalığın yol açtı̆̆ hüzünlü tablolar karşısında zekâ ile verem arasında sağlam bağlar olduğu yönünde çok tuhaf bir kanaat de öne sürüldü. Bazı sanatçılar veremli gibi davranırlarken bazıları büyük bir şair olmanın yolunun veremli olmaktan geçtiği safsatasını savundular. ${ }^{21} 1884$ 'te Paris'teki 56.970 vefatın 15.000 'i veremden kaynaklandı. ${ }^{22}$

Osmanlı sinırlarında da hastalık büyük kaygılara ve tahribatlara yol açtı. Osmanlı arşivinde yer alan belgelerden birinde Zeliha Hatun'un verem olma potansiyeline sahip Sabri isimli çocuğunun okuldan uzaklaştırılmasının ${ }^{23}$ ve diğerinde hastalığa yakalanan Lüleburgaz Rüştiye Mektebi Muallim-i Evveli Mustafa Efendi'nin emekliliğe sevk edilmesinin tedbirlerden görülerek uygulamaya konulduğuna yer verildi. Bu iki örnekten Osmanlı topraklarında da veremin yol açtı̆̆ı tedirginlik çok açık bir şekilde görülebilmektedir. ${ }^{24}$ Buna karşın bir Osmanlı arşiv belgesine göre, Fransa'da resmi istatistiklere nazaran 280.000 civarındaki askerden her y1l 36.000 kişi vefat etmekteyken İstanbul'da verem hastalı̆̆ının görülme sıklı̆ğ oldukça düşüktü. Bütün hastalara oranlandığında veremliler, genel tabloda \%o11-12 kadard. Veremliler, askeriyede ihraç edilen ya da emekliye ayrılanlar haricinde genel ölümün içerisinde 1/7 oranına sahiptiler. Bu veriler göre, Osmanlı Devleti ile Avrupa arasında veremin yol açtığı yıkım bakımdan çok ciddi fark vardı. ${ }^{25}$

Bu kıyasa ek olarak veremin yol açtığı kıyıma dair İnci Hot'un verdiği bilgilere de değinelim. Ona göre, İstanbul'da 20. Asrın başından Cumhuriyetin ilanına değin veremden her sene yaklaşık 2.800 kişi yaşamını yitirdi. Bu yıllarda meydana gelen bütün ölümler içinde bu sayı, yüzde 15 ile yüzde 8 arasına tekabül etti. 200.000 civarında nüfusa sahip olan İzmir'de 1890-1914 yılları arasında nüfusun yüzde 15,8 'ine denk gelen 14.700 kişi veremden öldü. İstanbul'a ilişkin farklı bir veri ise, veremden ölümün 1919 y1lında özel takibi yapılmaya çalışılan ve her bir ölümlü vakanın haber verilme zorunluluğu olan hastalıkların yol açtığı vefat sayısının 3 katından 10 fazla olmasiydi. ${ }^{26}$

Gerçekten de Batı'da ve Osmanlı'da veremin sebep olduğu yıkımın boyutları hayli dikkat çekicidir. Bununla beraber verem, insanların kolay sakınabilecekleri hastalıklardandır. 21. Asırda tıp camiasının belki de en çok üzerine durduğu "koruyucu hekimlik" uygulamasının ilkeleri ile

20 Nikiforuk, Mahşerin Dördüncü, s.177.

21 Nikiforuk, Mahşerin Dördüncü, 165.

22 COA, Y.PRK.ASK, Dosya No:139, Gömlek No: 92, Tarih: H.12.01.1316 ( 02.06.1898).

23 COA, M.F, MKT, Dosya No:7, Gömlek No: 130, Tarih: H. 20.10 .1289 (21.12.1872).

24 COA, MF.IBT, Dosya No: 9, Gömlek No: 60, Tarih: H.13.11.1293( 30.11.1876).

25 COA, Y.PRK.ASK, Dosya No:139, Gömlek No: 92, Tarih: H.12.01.1316 ( 02.06.1898).

26 İnci Hot, “Tanzimat Sonrası Osmanlı"da Bulaşıcı Hastalıklarla Mücadele”, Osmanlı'da Salgın Hastalıklarla Mücadele, Editörler: İbrahim Başoğlu vd, Çamlıca, İstanbul 2015, s. 125. 
hastalık sağlam bedenlerden uzak tutulabilmektedir. Bu uygulamada, temel prensip olarak kişilerin sağlıklı kalabilmeleri için beslenme, uyku düzeni ve spor gibi vücudu dinç kılacak şeylere riayetleri ile sigara, alkol ve madde bağımlığı v.s hastalığa yol açacak zararlı etkenlerden uzak durmalarına vurgu yapılmaktadır. Benzer biçimde nasihatnâmede de koruyucu hekimlik uygulamasının ilkelerinden bir kısmına "verem mikroplarının bize gelmemesi için tedbirler" başlığ 1 altında şu maddelerle yer verilmektedir:

Herkes sağlam olsun, hasta olsun...tehlikesiz, zararsı bir hale koymak kendisine vazife eylemelidir. Zira otururken, içinde verem mikrobu olup olmadığ 1 bir bakışta anlaşılmaz. Şu halde dört duvar içerisinde, çatı altında kapalı mahallerin yerlerine kimse tükürmemelidir! "Sokaklara, şimendifer, tramvay, beygir arabalarına" hiç olmazsa herkesin çok geçtiği yollara tükürmemelidir! Her tarafa tükürrük hakeleri koymalıdır! "Mekteplere, ksşlalara, dairelere, mağazalara ve fabrikalara mutlaka tükürrük hakeleri lazımdır. Eller mutlaka sık sık temizlenmelidir." "En sağlamı yarım saat kaynatmakla" hakelerin içlerine mikrop soldurucu ...koymakla da temizlenir. Öksürürken elini ağzının önüne tutmalıdr! ve yanındakine arkasını çevirmelidir! Elbiseleri temiz tutmalı, sık sık temizlemeli, kadınlar fistanlarını, erkekler paltolarını sürüklemelidirler! Sokaklarda, evlerde, mağaza, fabrika, klşla ve mekteplerde mümkün olduğu kadar toz olmamasina gayret etmelidir! Yerlere tükürülen mahalde oturma! Oralardan sakın geçme! Tozlu yerlerden kaç! Kimsenin elini yüzüne öpme! Kendini ve çocuklarını kimseye öptürme!

Yenilecek şeylerin hazırlanma ve muhafazasında sikı temizlik lazımdır. Sineklerden sakınmalı! Hususiyle çiğyenecek şeyler için daha ziyade dikkat gerektir! Süt içilmezden evvel iyice kaynatılmalıdır! ve kaynamış süt kapalı ve mümkün olduğu kadar serin saklanmalıdır.

Eller hususiyle tırnaklar, dişler, ağzın her tarafi sık s1k iyice temizlenmelidir! Elleri ağza sokmamalı, parmaklarla burun karıştırmamall, kirli ellerle yüzünü kaşımamalıdır. Her yarayı münasip bir sarı̆̆ bile kapatmalıdır! ${ }^{27}$

Veremle mücadeleye dair bilgi veren Osmanlı arşiv belgesinde de vereme yakalanan çocukların gerekli tedbirlerin alınması durumunda hastalığı atlatabileceklerine değinilmektedir. Vereme yakalanmaya meyilli olanlara mikropların daha kolay bir biçimde yerleşebileceği ve bu kişilerde veremin zuhur edeceği yazılmaktadır. Bu durumda olan "müteverem bir validenin çocuğu mukteza-yl şefkat ve saika-yı zaruretle" bardak gibi kişisel eşyasının ortak kullanımıyla hastalığın aktarımının gerçekleşeceğinin üzerinde durulmaktadır. Hastalıkla mücadelede, en çok önem verilmesi gereken ilkelerin başında veremli hastanın kişisel eşyalarını yalnızca kendisinin kullanması gerekliğinin altı çizilmektedir. Ameliyat sırasında tabiplerden vereme yakalananların çok sayıda kişinin olduğuna da yer verilmektedir. 1889 yılında Paris'te, bir hastanede hizmetçi kadınlardan birinin veremlilerin tükürük kaplarını temizlerken kazara düşürmesi sonrasında kırık parçaların elini yaraladığı ve veremin bulaşması ile yirmi gün gibi kısa bir süre içerisinde hayatını kaybettiği bilgisi aktarılmaktadır. Diğer taraftan Tapanir adlı bir kişinin bazı hayvanları bir yere hapsettiğinden ve verem mikrobunu barındıran balgam ile dolan havanın hayvanların tamamının hastalığa yakalanmasına yeterli olduğundan ve hayvanlarının tamamının öldüğünden bahsedilmektedir. İneklerde de çokça görülen vereme karşı sütlerin kaynatılması ve etlerinin de baytarların muayenelerinin ardından tüketilmesi tavsiye edilmektedir. ${ }^{28}$

27 "Vereme Karşı Nasihatler", s.4.

28 COA, Y.PRK.ASK, Dosya No:139, Gömlek No: 92, Tarih: H.12.01.1316 ( 02.06.1898). 


\section{Vereme Karşı İnsan Bünyesinin Sağlam Tutulması İçin Diğer Bazı Tavsiyeler}

2000'li yıllarda hekimlerin kanser gibi büyük hastalıkların meydana gelme sebeplerini açıklarken üzerinde en çok durdukları sebeplerden biri kişilerin psikolojik durumlarıdır. 1950'lerin sonlarında Glasgowlu David Kissen de veremle mücadele bağlamında tüberkülozun gelişiminde ruhi durumların etkisini ortaya çıkardı. Farklı tarihlerde incelediği 267 hastanın üçte biri tüberkülozluydu. Ortak özellikleri ise, yarısından fazlasının sevdikleri, nişanlıları ya da eşleri ile ilişkilerini istedikleri biçimde sürdüremedikleri ve bazılarının münasebetlerini hiç de istenilmeyecek biçimde sonlandırmış olduklarıydı. Hastalığın pençesine düşmeyenlerin de sadece dörtte biri, ruhi hallerini alt üst eden sorunlar yaşamıştı. Kissen’e göre, iyileşme eğilimde olan hastaların benzer bir durumla karşılaşmaları da hastalığın yeniden ortaya çıkmasına da neden oldu. İlgi ve sevgiden mahrumiyet ile yakın çevre ile sıkıntılar yaşanması insanların daha kolay hastalığa yakalanmalarına da yol açmaktaydı. ${ }^{29}$

Bireylerin aile ya da yakın çevreleri ile ilişkilerinde yaşadığı sorunlar başta olmak üzere günlük hayatını etkileyebilecek her türlü olumsuz gelişme beraberinde vereme yakalanmaya davetiye çıkarmaktadır. Ayrıca, vereme yol açan mikroplar tamamen ortadan kaldırılamayacağından hastalığa yol açan mikroplardan kaçışta söz konusu değildir. Bu bakımdan hasta olmamak ya da hasta olduğunda şifaya kavuşmak için yapılması gerekenlerin neler olduğu sorusu çok önemlidir ve belirtilen soru nasihatnâmede yanıtlanmaktadır. Nasihatnâmeye göre, vücut dışarıdan gelen mikroplara karşı dayanıklı olabilmesi için kuvvetlendirilerek sağlam tutulmalıdır. Böylece mikropların saldırısı karşısında bünye sağlam kalabilecek ve zararlıları yenilgiye uğratabilecektir. Yine nasihatnâmede mikroptan korunmak için yapılması gerekenler maddeler halinde şu şekilde siralanmaktadir:

Sade ve kuvvetli g1da: Yemeğinizi intihap etmesini ögreniniz! İyi ve kuvvetli yemek pahalı değildir. İçkilerden ve çerezlerden sakınınız!

Güneşin ve havanın bol ve kolay girdiği bir ev: Daha iyisi şehir dâhilinde olmayıp şehir haricinde olmasıdır. En iyisi odayı yatak odası ayırmalıdır!

Gevşek sürülmüş dayanıklı kumaştan yapılmış sade elbiseler: Elbiseler ne çok sıcak ne de çok serin tutar olmalıdır. Yürürken, işlerken çok ısınıp terletmemelidir. Korse, karın kuşağı, ask1 gibi vücudun hareket serbestîsini mani eden moda eşyasını terk etmelidir.

Yaşamanın her yolunda, her şeyden evvel temizlik, düzgünlük olmalıdır! Her gün bütün vücudunu serin bir suyla iyice yıkanmalıdır: Hiç olmazsa vücuda serin, rutubetli bir bezle süratle ovmalıdır veya temiz bir deniz veya çay banyosu yapılmalıdır veyahut başını ıslatmadan su dökün! Saç, sakal, bıyık, dişler, ăğı ve tırnaklarınızı sık sık temizle!

Nefes alırken ăgzını kapayıp, burundan hava al. Burun, muzır ve tehlikeli şeylerin hava ile vücuda girmemesi için iyi bir süzgeçtir. Eğer burundan iyi nefes alamıyorsan hemen erbabı hekime göster ve başlangıçta çok kere zor nefes almanın giderilmesi kolaydır.

İşine yoluyla ve bütün arzunla çalış! Bu sana tekrar kuvvet getirir. Tutacağın işi, sanatı öyle seçki hem isteğine uysun hem de să̆lı̆̆ına yarasın: Sana ögrettiğimiz şu nasihatlerin hepsinden hisse al! Zihnin ile çalışırken bile bugün oturmaktan sakın! Eğer birisini çalıştırıyorsan, iş ustası 
isen çalıştırdlğın adamlara zararlı iş gördürme! İşinde çalışanlara zarar verecek şeyler varsa bunları büsbütün kaldıramazsan hiç olmazsa mümkün olduğu kadar azalt ( toz, duman, rutubet, güneş, ziyasızlık gibi). Çalışmak ve istirahat münasip surette taksim olunmalıdır! Çalışan vücut istirahat ister.

İşsiz zamanında vücudunu kuvvetlendirmeye uğraş! Zira iş zamanında bunun için firsat pek azdır: Açık yerlerde hareketler yap, kollarını yan taraflarına açarak yavaş ve derin nefes al! İyi hava olduğu gibi fena havada da açık havaya çıkmaya alış! Kunduraların, elbiselerin ıslanırsa hemen değiştir. Açıkta yapacă̆ın hareketlerle vücudun ıslanırsa hemen değiştir. Açıkta yapacağın hareketlerde vücudun ile başın ile mütenasip olsun! Yürümek, top, oynamak, mutedil bir surette ata binmek, kürek çekmek ve emsali vereme karşı koymak için en iyi silahlardır. Fakat hiç birinde ifrata gitme! Sonra korktuğuna uğrarsin.

Vaktinde yatmalısın! Kendini her türlü sefahatten sakın. Sonra çok zamanda kazandığını az zamanda kaylp edersin. İyi büyümüs sağlam bir vücuda günde bir fincan hafif kahve, bir bardak çay, bir sigara- münasip zamanda kullanmak şartiyla- az zarar verir. Bir insana bu kadar keyif kâfidir. Bunların fazlası fazla zarar verir. Salgın hastalığı olanlarla görüşme! Görüştüklerini içinde veremli olmasın! Eğer vazifen veya sanatın bu kişilerle görüş̧meye, beraber yaşamaya mecbur ediyorsa öğrendiğin nasihatleri hiç zihninden çıkarma! Hepsini yapmaya gayret et. Yeni bir eve taşınır isen onu mutlaka hâkimce temizlettir. ${ }^{30}$

$\mathrm{Bu}$ nasihatlerin ardından vereme yakalanma eğiliminde olanların tavsiyelere uymak için gayret sarf etmeleri gerektiğinin üzerinde de durulmaktadır. Bedensel ve ruhsal sorunları olanların hastalığın tuzağına daha kolay yakalanabilecekleri belirtilmektedir. Risk grubunda yer alanların fiziksel detaylarına ilişkin tasvire de girilmektedir. Bunlar, zayıf ve yeterince gücü olmayan, uzun bir boya sahip olmakla beraber kırılgan bir yapısı olan ve gögüs bölgeleri düz ve geniş bir görünümden uzak olanlardır. Vereme kolay tutulmaya yol açan etkenler arasında ailede hastalığın görülmesi de sıralanmaktadır. Bilhassa anne ve babaları veremli olanlarla veremli aile fertlerinin varlığı ya da veremlilerin bakıcılığının üstlenilmesi de hastalığa kapı aralamaktadır. Verem hastalığının risk grubunda bazı meslek erbabı da yer almaktadır. Sokak süpürücüler gibi çeşitli yollarla tozla temasları olanlarında tehdit altında bulundukları belirtilmektedir. Günümüzde önemli nefes darlığı hastalıklarından olan astım ya da koah ile kalp, şeker, tansiyon gibi kronik hastalıklardan bir ya da birden fazlasına sahip olanların diğer bir hastalığın daha çok tehdidi altında bulunduklarına dair uyarının bir benzeri de yapılmaktadır. Boğmaca öksürüğü, kansızlık, influenza, kızıl, şeker hastalığı gibi hastalıkları olan ya da atlatanların daha çok risk altında bulunduğuna değinilmektedir. Her ne sebeple olursa olsun çok kan kaybedenlerin de benzer durumda olduğu vurgulanmaktadır. ${ }^{31}$

Nasihatnâmeye göre, vücutları olası bir veremle mücadelede dirençsiz kalacak kimselerin günlük geçimlerini sağlayacakları işleri, kendi hassas vaziyetlerini göz önüne alarak seçmeleri de gerekmektedir. Bedenin dinçliğini artıracak şekilde hareketler yapmaya imkân sunan işler, kapalı mekânlarda yürütülen işlere nazaran daha yararlıdır. Kışın soğuklarda yüz felci gibi rahatsızlıklara da yol açan sert havaya karşı gereken önlemlerin alınmaması halinde insanlar daha kırılgan olacaklardır. Bu havalarda çok konuşulması, vücudun üşütülmesi ve aşırı yürüyüşlerin zararları dokunacaktır. Okullar, oteller, pansiyonlar, fabrikalar, mağazalar, darülacezeler, kışlalar, tiyatrolar

\footnotetext{
30 "Vereme Karşı Nasihatler", s.4.

31 "Vereme Karşı Nasihatler", s.4.
} 
ve gazinolar gibi çok sayıda insanın birbirlerine temas etmelerine yol açan ortamlardan uzak durmaya da azami özen gösterilmelidir. Gerekli tedbirlere başvurulmaması halinde, taşıyıcı bir veremlinin hastalığı kolayca aynı ortamı teneffüs ettiği kişilere bulaştırması kaçınılmazdır. ${ }^{32}$

\section{Verem Olanlar Ne Yapmalıdır?}

Nasihatnâmede, veremin tanımı ve veremle mücadele hususunda yapılması gerekenlere yer verildikten sonra hastalığa yakalananların aynı zamanda vazife hükmünde yapmaları gerekenlerin üzerinde de durulmuştur. Bu başlıkta öncelikle olarak, hangi durumlarda veremden şüphelenilmesi gerektiğine yer verilmektedir. Burunların iç bölgelerinde ve ciğerlerinde kısa sürede atlatılamayan, "şüpheli bazı alaim-i pusula" nın görülmesi, zaman zaman git gellerle tekraren ortaya çıkması durumunda ve kuru veya balgamlı öksürüğün eşlik ettiği yakınmalar ile boğaz, göğüs ve sırt bölgelerinde ara ara kendini hissettiren ağrıların olması durumunda vereme yakalanılmış olunabilineceğinin altı çizilmektedir. Bu belirtilerin yanı sıra sürekli bir kırgınlık ve yorgunluk, iştahsızlıkla birlikte sürekli kilo kaybı, akşamları kendisini gösteren aşırı hararet ile gece terlemesi ve tükürükte kan parçacıkları ya da boğazdan bolca kan gelmesi durumunda vakit kaybetmeksizin bir doktora müracaat edilmesi gerektiği tavsiye edilmektedir. Nasihatnâmeden bağımsız olarak 2011 yılında vereme karşı bilinçlendirme faaliyetleri kapsamında Sağlık Bakanlığı tarafından hazırlanan yayında veremin çok sinsi bir hastalık olduğundan bahsedilmektedir. Hastalığın vücuda girmeye başlaması ve bünyeyi kaplaması ile yavaş yavaş şikâyetler başladığına yer verilmektedir. Genellikle hastalar, ilk belirtileri görmezden gelirler, gelişmekte olan hastalığın başka bir nedenden kaynaklandığını düşündüklerine değinilmektedir. Buna bağlı olarak bir doktora müracaatları da gecikebilir. Bu erteleme hali hastalığın vücutta daha geniş bir alana yayılmasına, yıkımını artırmasına ve diğer bireylere daha fazla bulaşmasına neden olduğuna yer verilmektedir. $\mathrm{Bu}$ bakımdan iki haftayı aşan öksürük gibi gündelik yaşamı da etkileyen belirtiler görüldügünde doktora başvurulması tavsiye edilmektedir. ${ }^{33}$

Nasihatnâmede, balgamda verem mikroplarının aranması gerektiğine de değinilmektedir. Bütün bu belirtiler, kişilere verem hastalığı tanısının koyulmasına yardımcı olurlarken, verem mikrobunu taşımayanların daha önce değinilen tavsiyelere uymaları gerektiği yazılmaktadır. Vereme yakalanma durumunda, doğrudan doktora gidilmesi ve verdikleri tavsiyelere uyulmasi gerektiği ifade edilmektedir. Doktorların verdikleri tavsiyelere harfiyen uyulmaması durumunda bir süre sonra hasta için ilaçların fayda vermeyecek hale gelebileceği ve hastanın mevcut durumunu ciddiye almamasının cezasını çekmek zorunda kalacağı dile getirilmiştir. Bu uyarıyı takiben, verem hastalarının iki sorumluluğunun olduğuna dikkat çekilmiştir. Bunlardan ilki, bir an evvel hastalığ atlatmak kaydıyla, içinde yaşadığı topluma ve bütün insanlığa faydalı olmaya gayret sarf etmesidir. Diğer sorumluluk ise, aile fertleri başta olmak üzere, ilişki içerisinde bulunduğu bütün fertlere hastalığın sirayet etmemesi için azami gayret göstermesidir. ${ }^{34}$

32 "Vereme Karşı Nasihatler", s.4.

33 Verem (Tüberküloz) Hastaları ile Hasta Yakınlarını Bilgilendirme Rehberi ve Veremli Hastaların Hak ve Sorumlulukları, Editörler: Recep Akdağ v.d, Başak Matbaacılık ve Tanıtım Hizmetleri Ltd. Şti, Ankara 2011, s. 6.

"Vereme Karşı Nasihatler", s.4. 
İnsanların veremin balgam ve tükürüğünü hafife almaması da son derece önemlidir. ${ }^{35} \mathrm{Bu}$ noktada Veremle Mücadele Cemiyeti'ne göre veremli hastanın balgamının ortadan kaldırılması gerekmektedir. Bu hastalar, tükürüklerini özensizce ortak kullanım alanlarına saçmamalıdırlar. Tükürüklerini atabilecekleri tükürük hokkalarına ya da bez parçalarını yanlarında bulundurmaları ve öksürdüklerinde mendil veya bir kumaş parçasını bir şeyle ağızlarını kapatmaları zaruridir. ${ }^{36}$ Nasihatnâmenin tavsiyesince de verem hastaları yerlere tükürmekten ve tükürüklerini yutmaktan sakınmalıdırlar. Tükürüklerini daha çok kolayca temizleyebilecekleri bir kaba çıkarmalıdırlar. Hastalığın bulaşıcı etkisinin kırılması için, sık sık temizlemek kaydıyla, üzerlerinde rahat bir biçimde taşıyabilecekleri tükürük hakeleri kullanmalıdırlar. Mecburiyet hali dışında mendilleri tek kullanımlık olmalıdır. Mendilleri, birden fazla kere kullandılarsa, vakit kaybetmeden uygun bir zamanda kurutmalıdırlar. Mendillerin içindeki tükürük parçaları toz haline gelmeden kaynatılmalı ve mikropların çoğalmasına firsat vermeden etkisiz hale getirmelidirler. Veremden sakınmak için öpmeye ya da öpülmeye müsaade edilmemelidir. Verem oldukları belli olan kimselerin, hastalığın bütün emareleri ortadan kalkıncaya kadar, evlenmelerine ruhsat verilmemelidir. Emzirme döneminde olan veremli kadınlar, hastalığın bebeğe geçmemesi için bebeklerini emzirmemeliler ve çocuklarının bakımları ile ilgilenmemelidirler.

Hastalığın ilerlemesi ile hissedilen ateş derecesi artabilecek ve ağızdan kan gelmeye başlayabilecektir. Budurumlarlakarşı karşıyakalınması halinde istirahatınkapsamı genişletilmelidir. Veremli hastaların pek çok hastalığın üstesinden gelinmesi safhasında önemli bir unsur olan güneş ışınlarından istifadesi artırılmalıdır. Ciğerlere doğrudan zarar veren toz ve dumanı içeren havalardan kaçınılarak temiz havalarda vücudun sağlam kalmasını sağlayacaktır. Veremlilerin hastalıklarının daha az sancılı ve tedavi sürelerinin daha kısa olmasını sağlayan unsurların başında her bir tarafı açık mekânlardan uzak kalarak üç taraftan kapalı bir alanda uzanıp dinlenmeleri de gelmektedir. Bu tedbir ve tavsiyelerin tamamına riayet edilmesi gerekmekle birlikte yine de işinin ehli doktorlarla hizmet veren bir verem hastanesine gidilmesi önerisinde bulunulmaktadır. Vereme karşı savaş veren bir sanatoryumda üç ay müddetince görülecek tedavi ile hastaların sağlıklarını kavuşmuş olarak tedavi edileceklerdir. Bu tedavinin ardından kişiler genel sağlık kurallarına dikkat ederler ve vereme tekraren yakalanmamak için gerekli tedbirlere riayet ederlerse hastalık bir daha nüksetmemek üzere ortadan kalkacaktır. Bir hayli yorucu ve uzun bir uğraşın ardından insanlar gündelik yaşamlarına dönebilecektir. Bireylerin içinde yaşadıkları topluma karşı vazifeleri bağlamında gerekli uyarılara dikkat etmeleri ile bulaşıcı hastalıkların daha fazla tahribata neden olmaları engellenecektir. ${ }^{37}$

35 "Vereme Karşı Nasihatler", s.4.

36 "Veremi Ortalığa Yaymaktan Sakınmalı", Sıhhi Cidal Dergisi, S. 11, İzmir Veremle Mücadele Cemiyeti Bilgi Matbaas1, 1925, s. 13.

37 "Vereme Karşı Nasihatler", s.4. 


\section{Sonuç}

1894 Paris ve 1897 Venedik Sağlık Konferansları, salgın hastalıkları ele almak üzere toplanmışsa da katılımcı devletler takındıkları tavırlarla Osmanlı topraklarına ve hukukuna müdahale etme firsatını yakaladılar. ${ }^{38}$ Salgın hastalıklarla mücadele merkezli düzenlenen bu toplantıların bir devletin içişlerine karışmaya değin çok geniş etkileri bulunması hayli ilginçtir. Bu toplantıların düzenlenmesine yol açan bulaşıcı hastalıklardan biri de veremdir. Osmanlı arşivinde, veremin çaresinin bulunması için gerek yurt içinde gerekse yurt dışında çalışmalar yapıldığını ve toplantılar düzenlendiğini haber veren birçok belgeye rastlanılmaktadır. Bu belgelerden birinde, 1905 senesi Teşrin-i Evveli'nde Paris’te düzenlenecek Beynelmilel (uluslararası) Verem Konferansına katılmak üzere Fransa Maslahatgüzarının takririnin ulaştığı bildirildi. ${ }^{39}$ Veremin devasının bulunduğuna da pek çok belgede yer verildi. ${ }^{40}$

Yine de konu edindiğimiz verem, Reşat Nuri'nin "Köylüler cahil insanlar hastalıktan sakınmasını, korunmasını bilmiyorlar. "Aman çoluk çocuğunuzu koruyun kollayın. Belki geçer" diyecek olursam klzlyorlar. "Biz çok şükür Müslüman insanlarlz. Hastadan iğrenmek günahtır” diyorlar" şeklinde devam eden cümlelerine de yansıdığı üzere, halkın hastalıklar konusunda bilinçsizliğinin de etkisi ile uzun yıllar en acılı hastalıklardan biri oldu. Reşat Nuri'nin eserinde de görüldüğü üzere Anadolu'nun ücra taşra kasabalarında da varlığını hissettiren salgın karşısında atılan küçük adımlarla Anadolu topraklarında veremle savaş konusunda zamanla genel bir seferberlik ruhu ortaya çıktı. Bu mücadelenin parçalarından biri de Peyam Gazetesi'nin sayfalarına taşınan "Vereme Karşı Nasihatler" adlı yayındır. Bu tavsiye metni ile veremin ne olduğu sorusu cevaplanmakta ve nasıl mücadele edilmesi gerektiğine dair oldukça faydalı bilgiler aktarılmaktadır. Verem hastalığı gibi çok sayıda ağır hastalığa yol açan mikropların gözle görünmeyecek derecede küçük olması ve sadece mikroskopla büyütülerek görülebileceği gerçeğinin üzerinde durulmaktadır.

Nasihatnâmede, veremin sinsiliğine binaen hastalık tehdidinin daima idrakinde olunmasına ve sağlam bünyelerin hastalığa yakalanmaması için riayet edilmesi gereken tavsiyelere dikkat çekilmektedir. Günümüz hekimlerin bir hastalıkla mücadelenin en iyi yolu olarak önerdikleri koruyucu hekimlik ilkelerinin üzerinde durulmaktadır. Hastalığın vücuda girmesi durumunda nelerin yapılması gerektiği hususuna da detayları ile yer verilmektedir. Osmanlı arşiv vesikaları ve diğer kaynaklarla ile desteklenen Peyam Gazetesi'nin okurlarının dikkatine sunduğu metin çerçevesinde ortaya çıkan makalemiz aynı zamanda bütün salgın hastalıklara karşı mücadelede riayet edilmesi gereken temel kuralları da içermektedir. Bu bakımdan detaylarına yer verdiğimiz nasihatnâme, farklı kaynaklarla zenginleştirilerek günümüzde ve gelecekte yaşanan ya da yaşanabilecek benzer salgın hastalıklara karşı nasıl davranılması gerektiğine dair çok kıymetli bilgiler ihtiva ederek olası hastalıklara karşı çözüm ve tedavi bağlamında bir çıkış noktası olabileceğinden bir hayli önemlidir.

38 M. Şakir Bey”in Hicaz Hatıraları, s.12.

39 COA, Y. A. HUS, Dosya No: 492, Gömlek No: 19, Tarih: H. 25.06.1323 (27.08.1905).

$40 \mathrm{Bu}$ belgelerden birinde, Agop isimli bir Osmanlı vatandaşının imzasını taşıyan telgraf göndererek, veremin çaresinin bulduğunu iletiyordu. Bkz: COA, Y. MTV, Dosya No:177, Gömlek No: 257, Tarih: H.15.01.1316 (05.06.1898). 


\section{Kaynakça}

\section{Arşiv Vesikaları}

Cumhurbaşkanlığı Devlet Arşivleri Başkanlığı Osmanlı Arşivi (COA)

Hâriciye Nezâreti Siyasi Kısım (HR. SYS.): Dosya No: 3, Gömlek No: 720, Tarih: M.08.06.1892.

Maârif İbtidai (MF.İBT.): Dosya No: 9, Gömlek No: 60, Tarih: H.13.11.1293( 30.11.1876).

Maarif Mektubi (M.F, MKT): Dosya No:7, Gömlek No: 130, Tarih: H. 20.10.1289 ( 21.12.1872).

Yıldız Arşivi Hususi Maruzat (Y.A.HUS.): Dosya No: 492, Gömlek No: 19, Tarih: H. 25.06.1323 (27.08.1905).

Y1ldız Mütenevvi Maruzat (Y. MTV.): Dosya No:177, Gömlek No: 257, Tarih: H.15.01.1316 (05.06.1898).

Y1ldız Perakende Askeri Maruzat (Y.PRK. ASK.): Dosya No:139, Gömlek No: 92, Tarih: H.12.01.1316 (02.06.1898).

\section{Ana Kaynaklar}

Halife 2. Abdülhamit”in Hac Siyaseti M. Şakir Bey'in Hicaz Hatıralarl, Hazırlayanlar: Gülden Sarıyıldız- Ayşe Kavak, Timaş, İstanbul 2009.

“Vereme Karşı Nasihatler”, Peyam, 13 Teşrin-i Sani 1329 (26 Kasım 1913).

\section{Araştırma Eserler}

Ayar, Mesut- Tarık Özçelik, “19. Asır Ortalarında Kadar Osmanlı’da Veba Salgın Tarihçesi”, Osmanlı'da Salgın Hastalıklarla Mücadele, Editörler: İbrahim Başoğlu vd, Çamlıca, İstanbul 2015, s.51-52.

Barış, İzzettin, "Çağlar Boyu Tüberküloz” 21. Yüzyılda Tüberküloz Sempozyumu ve II. Tüberküloz Laboratuarı Tanı Yöntemleri Kursu, Samsun, s.1-7.

Defo, Daniel, Veba Yılı Günlüğü, Çeviren: İris Kantemir, Türkiye İş Bankası Kültür Yayınları, İstanbul 2020.

Tuğluoğlu, Fatih, "Cumhuriyet'in İlk Döneminde Verem Mücadelesi ve Propaganda Faaliyetleri”, Yakın Dönem Türkiye Araştırmaları, S. 13-14, 2008, s.1-26.

Hot, İnci, “Tanzimat Sonrası Osmanlı"da Bulaşıcı Hastalıklarla Mücadele”, Osmanlı'da Salgın Hastalıklarla Mücadele, Editörler: İbrahim Başoğlu vd, Çamlıca, İstanbul 2015, s. 125.

Keskinbora, Kadircan, "Savaştaki Düşmanlardan Bir Diğeri: Tüberküloz”, Lokman Hekim Dergisi, S.6, İstanbul 2016, s.174-184.

Nikiforuk, Andrew, Mahşerin Dördüncü Atlısı, Çeviren: Selahattin Erkanlı İletişim, İstanbul 2008. 
Özdemir, Hikmet, Salgın Hastalıklardan Ölümler 1914-1918, Türk Tarih Kurumu, Ankara 2005.

Philby, H. STJ., Arabian Jubilee, Robert Hale Limited, London 1952.

Söylemezoğlu, Süleyman Şefik, Hicaz Seyahatnamesi, Hazırlayanlar: Ahmet Çaycı-Bayram Ürekli, İz Yayınc1lık, İstanbul 2012.

Veremi Ortalığa Yaymaktan Sakınmalı”, Sihhi Cidal Dergisi, S.11, İzmir Veremle Mücadele Cemiyeti Bilgi Matbaas1, 1925, s.13.

Uslu, Muzaffer Tayyip, Şimdilik, Yapı Kredi Yayınları, İstanbul 2017.

Verem (Tüberküloz) Hastaları ile Hasta Yakınların Bilgilendirme Rehberi ve Veremli Hastaların Hak ve Sorumluluklarl, Editörler: Recep Akdağ v.d, Başak Matbaacılık ve Tanıtım Hizmetleri Ltd. Ști, Ankara 2011, s.6. 
Ek 1: 13 Teşrin-i Sani 1329 Tarihli Peyam Gazetesi'nde Yer Alan "Vereme Karşı Nasihatler" Adlı Nasihatnâme

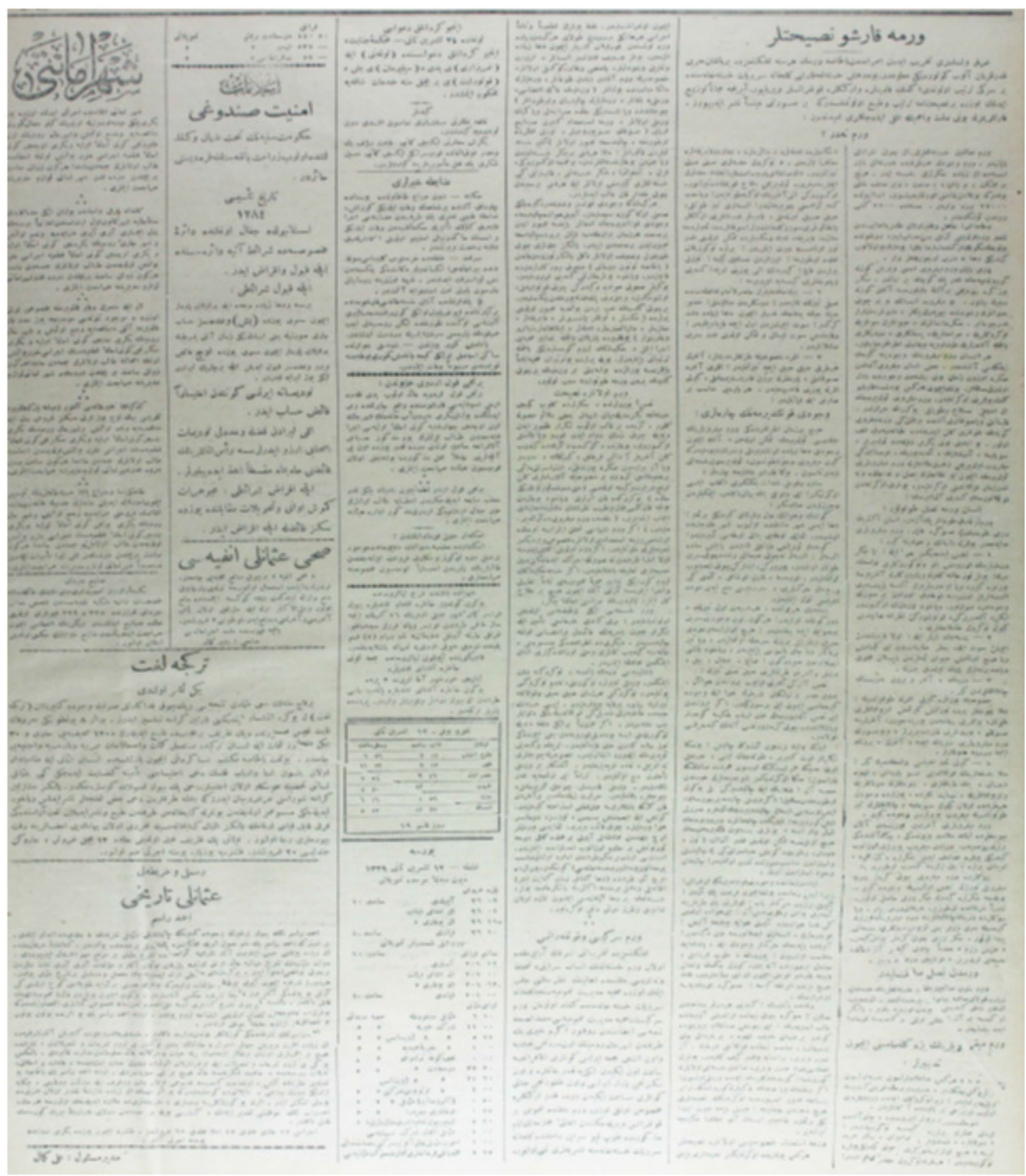

